\title{
Pengaruh Efektifitas Buah Pepaya Terhadap Kelancaran Produksi ASI Pada Ibu Nifas
}

\section{The Effect Of The Effectiveness Of Papaya Fruit On The Smooth Of Breast Milk Production In Public Mother}

\author{
Lety Arlenti ${ }^{1, *}$, Herlinda ${ }^{2}$ \\ ${ }^{1,2}$ Sekolah Tinggi Ilmu Kesehatan Sapta Bakti Jalan Mahakam Raya No. 16 Ligkar Barat Bengkulu, Indonesia \\ ${ }^{1}$ Lentiarlety@gmail.com*, ${ }^{2}$ herlindafh14@gmail.com \\ * corresponding author \\ Tanggal Submisi: 10 Januari 2021, Tanggal Penerimaan: 25 Januari 2021
}

\begin{abstract}
Abstrak
Penelitian ini bertujuan untuk mengetahui pengaruh konsumsi buah pepaya terhadap produksi ASI pada ibu nifas. Jenis penelitian ini kuantitatif dengan desain quasi experimental dengan pendekatan one group pretest-post test design. Sampel dalam penelitian ini sebanyak 30 responden dengan menggunakan teknik total sampling. Hasil penelitian yang dilakukan pada ibu nifas didapatkan hasil uji statistik menggunkan uji $\mathrm{T}$ berpasangan sesudah pemberian intervensi pemberian buah pepaya selama tujuh hari berturut-turut diperoleh $p$-value $=0,002<$ $\alpha(0,05)$, sehingga dapat disimpulkan bahwa terdapat pengaruh peningkatan produksi ASI sesudah dilakukan intervensi pemberian buah pepaya.
\end{abstract}

Kata kunci: kelancaran produksi ASI; buah pepaya

\begin{abstract}
This study aims to determine the effect of papaya consumption on breast milk production in post-partum mothers. This type of research is quantitative with a quasi experimental design with one group pretest-posttest design approach. The sample in this study were 30 respondents with total sampling technique. The results of research conducted on post-partum mothers showed that the statistical test using paired T-test after giving the intervention of papaya fruit for seven consecutive days was obtained p-value $=0.002<\alpha(0.05)$, so it can be concluded that there is an increase breastmilk production after papaya fruit intervention.
\end{abstract}

Keywords: smooth production of breast milk; papaya fruit

\section{PENDAHULUAN}

Menyusui merupakan suatu kejadian alamiah dan suatu seni yang harus dipelajari kembali, karena menyusui sebenarnya tidak saja memberikan kesempatan kepada bayi untuk tumbuh menjadi manusia yang sehat secara fisik saja tetapi juga lebih cerdas, mempunyai emosional yang stabil, perkembangan spiritual yang positif serta perkembangan social yang lebih baik (Roesli, 2013).

Masa nifas berlangsung selama 42 hari atau selama 6 minggu yang dimulai setelah plasenta lahir dan berakhir ketika alat-alat kandungan kembali seperti sebelum melahirkan (Anggraini, 2010). Pada masa nifas tersebut akan terjadi perubahan perubahan fisiologis, seperti perubahan ukuran uterus ke kondisi sebelum hamil, pengeluaran sekret cairan dari vagina, perubahan psikis dan fisik, dan laktasi atau pengeluaran Air Susu Ibu (ASI). Proses 
laktasi akan terjadi dan muncul perubahan pada kelenjar payudara ibu yang menyebabkan seorang ibu dapat memproduksi ASI (Turlina et al, 2015).

Manfaat pemberian ASI selain menurunkan Angka Kematian Bayi (AKB) juga memiliki manfaat bagi bayi dan ibu. Manfaat bagi bayi yaitu mengutip info yang diperoleh dari National Heath Service (Lembaga Pelayanan Kesehatan) Inggris, diantara manfaat pemberian ASI pada bayi adalah mengurangi risiko bayi terkena diare dan muntah, mengurangi kemungkinan terkena infeksi pada dada dan telinga, mengurangi risiko penyakit kulit, mengurangi terkena sembelit, sehingga berkurang juga kemungkinan bayi dirawat dirumah sakit. Menyusui anak juga memberi efek positif bagi sang ibu, antara lain mengurangi risiko ibu terkena penyakit jantung, mengurangi risiko terkena kanker rahim dan payudara, membakar kalori pada tubuh ibu, menghemat pengeluaran dan juga menumbuhkan ikatan yang kuat antara ibu dan anak. Selain itu menyusui anak juga menunda kembalinya siklus menstruasi pada ibu yang baru melahirkan (Roesli, 2013).

Kelancaran produksi ASI dipengaruhi oleh banyak faktor seperti, frekuensi pemberian ASI, berat bayi saat lahir usia kehamilan saat bayi lahir, usia ibu dan paritas, stres dan penyakit akut, inisiasi menyusu dini, keberadaan perokok, konsumsi alkohol, perawatan payudara, penggunaan alat kontrasepsi dan status gizi. Ketersediaan ASI yang lancar pada ibu menyusui akan membantu kesuksesan pemberian ASI eksklusif selama 6 bulan, sehingga membantu bayi tumbuh dan berkembang dengan baik sesuai rekomendasi dari WHO (Feriel, 2013).

Berdasarkan Survei Demografi Kesehatan Indonesia (SDKI) 2016 di Indonesia cakupan ASI eksklusif pada tahun 2016 mencapai 54\%, sedangkan cakupan pemberian ASI eksklusif tahun 2017 adalah 2.096 orang (61,2\%). Cakupan ASI ekslusif menunjukan kecenderungan menurun dibandingkan tahun-tahun sebelumnya. Cakupan pemberiaan ASI eksklusif tahun 2016 adalah 61,74 \%, tahun 2015 adalah 77,9\%, tahun 2014 capaian adalah 81,3\%, tahun 2013 adalah 78,7\%, dan capaian cakupan pemberian ASI tahun 2012 adalah 51,5\%. Cakupan pemberian ASI eksklusif berbeda-beda untuk masing-masing puskesmas. Cakupan pemberian ASI eksklusif tertinggi di Puskesmas Basuki Rahmat sebesar 87,5\%, dan cakupan pemberian ASI eksklusif terendah adalah Puskesmas Sukamerindu 9,3\% (Dinkes Kota Bengkulu, 2016).

Permasalahan yang sering terjadi pada ibu menyusui dimulai sejak masa kehamilan sampai masa nifas. Masalah menyusui dapat disebabkan karena masalah khusus. Bayi sering menangis dan tidak mau menyusu merupakan masalah yang sering terjadi (Utami et al, 2017). Dampak kurangnya pemberian ASI pada bayi yaitu dapat menyebabkan bendungan ASI, mastitis dan abses (Andriyani, 2014). Banyak ibu yang merasa bahwa susu formula itu sama baiknya atau malah lebih baik daripada ASI, sehingga cepat menambahkan susu formula tersebut apabila ASI kurang. Petugas kesehatan masih banyak yang tidak memberikan informasi pada saat pemeriksaan kehamilan atau saat memulangkan bayi (Astutik, 2014).

Faktor seorang ibu tidak dapat memberikan ASI eksklusif pada bayinya dapat disebabkan karena kurangnya pengetahuan ibu tentang ASI eksklusif, ada keterlambatan dalam memproduksi ASI sampai lebih dari 2 hari setelah melahirkan ASI belum keluar. Faktor lain adalah masalah pemahaman tentang arti ASI eksklusif dan pentingnya bagi pertumbuhan bayi, pengeluaran ASI yang tidak lancar. Pengeluaran ASI yang tidak lancar ini dapat distimulasi dengan konsumsi Carica Papaya L. Berdasarkan penelitian Kurniati et al (2018) menyebutkan bahwa pepaya muda (Carica Papaya L) merupakan salah satu latogogum alternatif yang dapat meningkatkan produksi ASI. Selain itu, Carica Papaya L juga mengandung saponin, alkaloid, mineral, vitamin dan enzim yang akan memberikan efek meningkatkan jumlah dan diameter kelenjar mamae. Getah dari papaya muda mempunyai efek yang sama dengan oksitosin pada uterus (Wulandari, 2011). Hormon oksitosin juga di sebut hormon cinta (UNICEF, 2011). 
Salah satu upaya ibu selama memberikan ASI secara ekslusif, harus mendapatkan tambahan asupan makanan untuk menghindari pengurangan produksi ASI. Laktagogum merupakan zat yang dapat meningkatkan atau memperlancar pengeluaran air susu. Laktagogum sintetis tidak banyak dikenal dan relatif mahal. Hal ini menyebabkan perlu dicarinya sumber laktagogum alternatif. Buah pepaya merupakan jenis tanaman yang mengandung laktagogum dan memiliki potensi dalam menstimulasi hormon oksitosin dan prolaktin yang berguna dalam meningkatkan dan memperlancar produksi ASI (Murtiana, 2011).

\section{METODE PENELITIAN}

Jenis penelitian ini kuantitatif yaitu penelitian dengan memperoleh data yang berbentuk angka atau kualitatif yang diangkakan Notoatmodjo (2010). Rancangan penelitian ini menggunakan desain quasi experimental dengan pendekatan one group pretes-posttest design. Jumlah sampel 30 orang ibu nifas $<7$ hari di BPM wilayah kerja Puskesmas Telaga Dewa Kota Bengkulu.

\section{HASIL DAN PEMBAHASAN}

Tabel 1. Hasil analisis produksi ASI sebelum dan sesudah diberikan buah pepaya pada ibu nifas di BPM wilayah kerja Puskesmas Telaga Dewa Kota Bengkulu, $(\mathrm{n}=30)$

\begin{tabular}{llcc}
\hline \multicolumn{1}{c}{ Variabel } & \multicolumn{1}{c}{ Mean \pm Sd } & $\begin{array}{c}\text { Perbedaan } \\
\text { Mean } \pm \text { Sd }\end{array}$ & P-Value \\
\hline Produksi ASI & $11,4364 \pm$ & & \\
sebelum intervensi & 0,30945 & $0,559 \pm$ & 0,002 \\
\hline Produksi ASI & $11,9955 \pm$ & 0,724 & \\
setelah Intervensi & 0,79790 & & \\
\hline
\end{tabular}

Berdasarkan tabel 1 yang dilakukan pada ibu nifas di BPM wilayah kerja Puskesmas Telaga Dewa Kota Bengkulu didapatkan hasil uji statistik menggunakan uji-T berpasangan sesudah pemberian intervensi pemberian buah pepaya tiga kali sehari sebanyak 600 gr selama 7 hari berturut-turut, di peroleh $p$-value $=0,002<\alpha(0,05)$, sehingga dapat disimpulkan bahwa terdapat peningkatan produksi ASI sesudah dilakukannya intervensi pemberian buah pepaya.

Faktor-faktor yang mempengaruhi pengeluaran ASI antara lain yaitu makanan, ketenangan jiwa dan pikiran ibu, penggunaan alat kontrasepsi, anatomi dada, faktor istirahat, isapan anak, dan obat-obatan (Kristiyansari, 2009). Laktagogram yang terkandung dalam buah pepaya memiliki potensi untuk menstimulasi hormon oksitosin dan prolaktin seperti alkaloid, polifenol, steroid, flavonoid dan substansi lainnya. Hormon-hormon tersebut paling efektif dalam meningkatkan dan memperlancar produksi ASI. Reflek prolaktin secara hormonal untuk memperlancar produksi ASI. Pada saat bayi menghisap puting payudara ibu, terjadi rangsangan neorohormonal pada puting susu dan aerola ibu. Rangsangan ini diteruskan ke hipofisis melalui nervos vagus, kemudian ke lobus anterior. Dari lobus ini akan mengeluarkan hormon prolaktin, masuk ke dalam peredaran darah dan sampai pada kelenjarkelenjar pembuat ASI. Kelenjar ini akan terangsang untuk menghasilkan ASI (Murtiana, 2011).

Produksi laktasi atau menyusui adalah proses pembentukan ASI yang melibatkan hormon prolaktin dan hormon oksitosin. Hormon prolaktin selama masa kehamilan akan meningkat akan tetapi ASI belum keluar karena masih terhambat hormon estrogen yang tinggi. Dan saat melahirkan, hormon estrogen dan progesteron akan menurun, sebaliknya hormon prolaktin akan lebih dominan sehingga terjadi sekresi ASI (Kumala, 2016).

Buah pepaya merupakan salah satu jenis buah yang memiliki kandungan enzimenzim, vitamin $\mathrm{C}, \mathrm{A}, \mathrm{B}$ dan $\mathrm{E}$, serta mineral. Kandungan kimia buah pepaya muda 
mengandung polifenol dan steroid. Peningkatan produksi ASI dipengaruhi oleh adanya polifenol dan steroid yang mempengaruhi reflek prolaktin untuk merangsang alveolus yang bekerja aktif dalam pembentukan ASI. Polifenol mempengaruhi hormon oksitosin yang akan membuat ASI mengalir lebih deras dibandingkan dengan sebelum mengkonsumsi buah pepaya (Istiqomah et al, 2015).

Peningkatan produksi ASI dipengaruhi oleh adanya polifenol dan steroid yang mempengaruhi reflek prolaktin untuk merangsang alveolus yang bekerja aktif dalam pembentukan ASI. Peningkatan produksi ASI juga dirangsang oleh hormon oksitosin. Peningkatan hormon oksitosin dipengaruhi oleh polifenol yang terkandung dalam buah pepaya muda yang akan membuat ASI mengalir lebih deras dibandingkan dengan sebelum mengkonsumsi buah pepaya. Oksitosin merupakan hormon yang berperan untuk mendorong sekresi air susu (milk let down). Peran oksitosin pada kelenjar susu adalah mendorong kontraksi sel-sel miopitel yang mengelilingi alveolus akan terdorong keluar menuju saluran susu, sehingga alveolus menjadi kosong dan memacu untuk sintesis air susu berikutnya (Nataria dan Oktiarini, 2018).

Hal senada diungkapkan dalam penelitian Kurniati et al, (2018) dengan metode eksperimen yang menggunakan rancangan sebelum dan sesudah intervensi menggunakan satu kelompok. Desain ini menggunakan one group before and after intervention design, atau pre and post test design yang dimana satu-satunya unit eksperimen tersebut berfungsi sebagai kelompok eksperimen sekaligus kelompok kontrol. Di dalam penelitian disebutkan bahwa rata-ratanya adalah 5,05 sedangkan setelah mengkonsumsi buah pepaya rata-ratanya mengalami peningkatan menjadi 8,20. Korelasi antara dua variabel adalah sebesar 0,005 dan perbedaan nilai rata-rata peningkatan produksi ASI pada ibu yang tidak mengkonsumsi dan yang mengkonsumsi buah pepaya adalah 3,15 dan dengan nilai sig=0,000. Dengan rutinnya ibu mengkonsumsi buah pepaya muda selama 7 hari berturut-turut, maka semakin terlihat peningkatan produksi ASI secara signifikan.

Penelitian Pattypeilohy dan Henukh (2018) menyatakan bahwa pengaruh pemberian air rebusan buah pepaya dalam meningkatkan produksi ASI ibu nifas memiliki pengaruh yang signifikan sebelum dan sesudah diberikan air rebusan buah pepaya. Terbukti dari $16 \mathrm{ibu}$ nifas yang menjadi responden, terdapat $14 \mathrm{ibu}$ nifas yang mengalami peningkatan produksi ASI setelah 7 hari pemberian air rebusan buah pepaya dan didukung juga oleh ibu yang rutin menyusui bayinya sehingga produksi hormon yang bekerja untuk proses pengeluaran ASI meningkat.

Hasil penelitian ini sejalan dengan penelitian Muhartono et al, (2019) menunjukkan bahwa rata-rata produksi ASI sebelum mengonsumsi buah pepaya adalah 5,7 kali dengan standar deviasi 0,8131 dan rata-rata setelah mengonsumsi buah pepaya adalah 9,75 kali dengan standar deviasi 0,78640. Karena perbedaan nilai rata-rata adalah 4,05000 dengan sig $=0,000$ sehingga sig $<0,05$, dapat disimpulkan bahwa ada perbedaan rata-rata produksi ASI sebelum dan sesudah mengonsumsi buah pepaya.

Kelancaran produksi ASI dapat dilihat dari ASI yang merembes dari puting susu, payudara terasa tegang, saat menyusui payudara terasa seperti diperas. Ibu akan merasa tenang karena tidak takut bayinya akan kekurangan ASI Prasetyono (2009). Bagi bayi dikatakan cukup ASI yaitu bayi kencing setidaknya 6 kali dalam 24 jam dan berwarna kuning jernih, bayi menyusu dengan sering setiap 2-3 jam atau 8-12 kali dalam sehari, bayi tampak puas dengan tidur yang cukup, bayi tampak sehat dengan warna kulit dan turgor baik, bayi bertambah berat badan rata-rata 500 gram perbulan Anggraini (2010).

\section{SIMPULAN}

Berdasarkan hasil penelitian dan pembahasan yang dilakukan pada ibu nifas di BPM wilayah kerja Puskesmas Telaga Dewa Kota Bengkulu dapat disimpulkan bahwa distribusi 
nilai rata-rata produksi ASI sebelum pemberian buah pepaya sebesar 11,4364 (SD=0,30945) dan mengalami peningkatan produksi ASI setelah pemberian buah pepaya yaitu rata-rata produksi ASI 11,9955 ( $\mathrm{SD}=0,79790$ ) yang artinya terdapat pengaruh efektifitas pemberian buah pepaya terhadap kelancaran produksi ASI di BPM wilayah kerja Puskesmas Telaga Dewa Kota Bengkulu.

\section{SARAN}

Hasil penelitian diharapkan dapat menjadi sumber informasi bagi ibu nifas sehingga ASI keluar lancar dengan jumlah yang cukup banyak, serta untuk ibu menyusui agar dapat memanfaatkan buah pepaya sebagai terapi komplementer untuk memperlancar produksi ASI, karena ASI adalah makan penting bagi bayi, dan sebaikya ibu memberikan ASI eksklusif sejak 0-6 bulan tanpa diberi makanan tambahan, dan dilanjutkan hingga usia 2 tahun didampingi dengan makanan tambahan untuk anak.

\section{REFERENCE}

Andriyani P. (2014). Asuhan kebidanan ibu nifas (Askeb III). Yogyakarta: Deepublish.

Anggraini Y. (2010). Asuhan kebidanan masa nifas. Yogyakarta: Pustaka Rihama.

Astutik. (2014). Payudara dan laktasi. Jakarta: Salemba Medika.

Dinkes Kota Bengkulu. (2016). Laporan Tahunan Dinas Kesehatan Kota Bengkulu Tahun 2017. Bengkulu: Dinas Kesehatan Kota Bengkulu.

Feriel EW. (2013). Biologi reproduksi. Jakarta: Erlangga.

Istiqomah dkk. (2015). Pengaruh buah pepaya terhadap kelancaran produksi ASI pada ibu nifas di Desa Wonokerto wilayah Puskesmas Paterongan Jombang tahun 2014. Journal Eduhealth, 5(2), 102-108.

Kristiyansari W. (2009). ASI, menyusui dan sadari. Yogyakarta: NuMed.

Kumala R. (2016). Panduan asuhan nifas dan evidance practice. Yogyakarta: Deepublish.

Kurniati D, Mardiyanti S, Suprihatin. (2018). Perbedaan produksi ASI dalam pemberian olahan buah pepaya pada ibu postpartum di BPM Maria Kota Bandar Lampung tahun 2018. Jurnal Ilmiah Kesehat dan Kebidanan, VII(2).

Turlina, Lilin RW. (2015). Pengaruh pemberian serbuk daun pepaya terhadap kelancaran ASI pada ibu nifas di BPM Ny. Hanik Dasiyem, Amd.Keb di Kedungpring, Kabupaten Lamongan. Surya, 7(1).

Muhartono, Graharti R, Gumandang HP. (2018). Pengaruh pemberian buah pepaya (Carica Papaya L) terhadap kelancaran produksi Air Susu Ibu (ASI) pada ibu menyusui. Medula, 8(April), 39-43.

Murtiana T. (2011). Buah pepaya. Jakarta: Pustaka Cipta.

Nataria D, Oktiarini S. (2018). Peningkatan produksi ASI dengan konsumsi buah pepaya. Jurnal Kesehatan Prima Nusantara Bukittinggi, 9(1), 7-10.

Notoatmodjo S. (2010). Metodologi penelitian kesehatan. Jakarta: Rineka Cipta.

Pattypeilohy, A., \& Henukh D. (2019). Pengaruh pemberian air rebusan buah pepaya dalam meningkatkan produksi ASI ibu nifas di Puskesmas Manutapen. CHMK Midwifery Sci $J, 2(2), 33$.

Prasetyono DS. (2009). Buku pintar ASI ekslusif: pengenalan, praktik dan pemanfataannya. Yogyakarta: Diva Press.

Roesli U. (2013). Mengenal ASI ekslusif. Jakarta: PT Pustaka Pembangunan.

Utami D, Widodo S, Fajarini YI. (2017). Pengaruh massage payudara terhadap kelancaran ekskresi ASI pada ibu postpartum di Puskesmas Jatinom. Jurnal Ilmu Kesehatan STIKES Duta Gama Klaten, 8(2). 
UNICEF. (2011). Pelatihan konseling menyusui. World Health Organization.

Wulandari. (2011). Asuhan kebidanan ibu nifas. Yogyakarta: Gosyen Publishing. 